DOI: $10.19195 / 0137-1134.109 .8$

JOLANTA BLICHARZ

Uniwersytet Wrocławski

\title{
ZAGADNIENIE CHARAKTERU PRAWNEGO STOWARZYSZEŃ JEDNOSTEK SAMORZĄDU TERYTORIALNEGO
}

\section{UWAGI OGÓLNE}

Jednym $\mathrm{z}$ istotnych argumentów przemawiających za utworzeniem stowarzyszeń jednostek samorządu terytorialnego było dążenie do zapewnienia właściwego, zgodnego z rzeczywistymi potrzebami, współdziałania między jednostkami samorządu terytorialnego $\mathrm{w}$ zakresie wspierania idei samorządu terytorialnego oraz obrony wspólnych interesów. Wprowadzenie instytucji stowarzyszeń samorządowych (komunalnych) oznacza głębokie zmiany, i to nie tylko w funkcjonowaniu gmin, powiatów oraz województw, lecz także - co znacznie rzadziej się podnosi - w sferze zapewnienia elastyczności rozwiązań prawnych.

Problematyka stowarzyszeń jednostek samorządu terytorialnego ma więc różne wymiary, a realizacja przyjętych założeń przebiega na wielu płaszczyznach oraz w różnym zakresie podmiotowym i przedmiotowym. Podobnie jak złożony jest sam problem, tak i zróżnicowane są kwestie prawne, i to zarówno o charakterze ustrojowo-organizacyjnym (chodzi o rodzaje stowarzyszeń komunalnych, ich zadania), jak i materialnoprawnym (wybór dziedzin — zakresu spraw i sposobu ich załatwiania przez wyróżnione podmioty). W różnym stopniu znajdują one wyraz w aktach prawnych.

W obowiązującym stanie prawnym podstawą współpracy w ramach stowarzyszeń jednostek samorządu terytorialnego są przepisy Ustawy z dnia 8 marca 1990 r. o samorządzie gminnym ${ }^{1}$, ustawy z dnia 5 czerwca 1998 r. o samorządzie powiatowym ${ }^{2}$, ustawy z dnia 5 czerwca 1998 r. o samorządzie województwa ${ }^{3}$ oraz ustawy z dnia 7 kwietnia 1989 r. Prawo o stowarzyszeniach ${ }^{4}$. Wyróżnione akty

\footnotetext{
1 Dz.U. 2016 poz. 446 z późn. zm.

2 Dz.U. 2015 poz. 1445 z późn. zm.

3 Dz.U. 2015 poz. 1392 z późn. zm.

${ }^{4}$ Dz.U. 2015 poz. 1393 z późn. zm.
} 
prawne stwarzają możliwość współpracy w ramach stowarzyszenia dla jednostek samorządu terytorialnego zarówno tego samego szczebla (np. gmin z innymi gminami), jak i jednostek samorządowych różnych szczebli (np. gmin z powiatami i województwami). Z punktu widzenia ich formy mogą to być stowarzyszenia jednorodne (lokalne i regionalne) oraz mieszane.

Kwestią sporną jest problem, czy ta forma organizacyjno-prawna oznacza wyłączenie z zakresu podmiotów administracji publicznej, i czy wobec tego można by posługiwać się rozróżnieniem: podmioty administracji publicznej a inne podmioty (np. stowarzyszenia jednostek samorządu terytorialnego) - w znaczeniu tradycyjnym.

Podjęte kwestie wydają się istotne, albowiem z formalnoprawnego punktu widzenia sprawa charakteru prawnego stowarzyszeń komunalnych nie jest rozstrzygnięta. Ze względów teoretycznych, opierając się nadto na obowiązującym ustawodawstwie, nie byłoby uzasadnione pominięcie tych instytucji w całokształcie działalności samorządu terytorialnego. Służą one bowiem w szczególny sposób wspieraniu jego idei na tak ważnym odcinku, jakim jest wykonywanie zadań publicznych. Nie może to oczywiście oznaczać równorzędnego ich traktowania z jednostkami samorządu terytorialnego jako samodzielnymi podmiotami administracji.

\section{STOWARZYSZENIA KOMUNALNE A JEDNOSTKI SAMORZĄDU TERYTORIALNEGO}

Dla określenia charakteru prawnego stowarzyszeń komunalnych ważne jest rozstrzygnięcie pomiędzy dwoma różniącymi się dość zasadniczo poglądami: czy działalność tych podmiotów mieści się w sferze działalności samorządu terytorialnego, czy też ich celem jest rozwiązywanie własnych spraw.

Dla dokonania ustaleń teoretycznych należałoby podnieść w pierwszym rzędzie problem osobowości prawnej w znaczeniu nadanym mu w obowiązującym prawie, a także jej wpływu na kształtowanie pozycji prawnej stowarzyszeń komunalnych. Nie można nie docenić tej formy wyodrębnienia prawnego w sferze działalności samorządu terytorialnego. Przy czym posłużenie się kryterium osobowości prawnej eliminuje możliwość rozważania na jednej płaszczyźnie pojęciowej stowarzyszeń komunalnych i jednostek samorządu terytorialnego jako podmiotów administracji.

Nie podlega dyskusji, że stowarzyszenia jednostek samorządu terytorialnego i jednostki samorządu terytorialnego posiadają osobowość prawną ${ }^{5}$. Wynika to z obowiązującej u.p.s. (art. 8 ust. 1 w zw. z art. 84 ust. 3 u.s.g i art. 75 ust. 2 u.s.p. oraz art. 8 b ust. 2 u.s.w). Natomiast w odniesieniu do jednostek samorządu terytorialnego (gmin, powiatów, województw samorządowych) wynika to jedno-

${ }^{5} \mathrm{~W}$ ujęciu prawnym osoba prawna jest tworem, który przez normy prawne został wyposażony w zdolność prawną i zdolność do czynności prawnych. 
znacznie z Konstytucji RP (art. 165) ${ }^{6}$ i z przepisów ustaw ustrojowych (art. 2 ust. 2 u.s.g., art. 2 ust. 1 pkt 2 u.s.p. oraz art. 6 ust. 2 u.s.w.). Problem jednak w tym, że osobowość prawna jednostek samorządu terytorialnego to podmiotowość szczególnej osoby prawnej w zakresie norm prawnych prawa publicznego i prywatnego. Z faktu, iż korporacje te wykonują zadania samodzielnie - w imieniu własnym i na własną odpowiedzialność — przypisujemy im przymiot podmiotowości publicznoprawnej, odrębnej od państwa ${ }^{7}$. Jakkolwiek ustawodawstwo polskie nie wprowadza wprost pojęcia osobowości publicznoprawnej i nie przyznaje jednostkom samorządu terytorialnego osobowości prawa publicznego, to jednak uznanie publicznoprawnego charakteru samorządu terytorialnego pociąga za sobą wiele istotnych konsekwencji. Do najważniejszych z nich należałoby zaliczyć: udział samorządu terytorialnego w sprawowaniu władzy publicznej (art. 16 ust. 2 Konstytucji RP) (przynależność „,mieszkańców wspólnoty” do danej jednostki samorządu terytorialnego powstaje ipso iure, tym samym nie można mówić o członkostwie w samorządzie - można natomiast być członkiem organu samorządu), powołanie samorządu w celu wykonywania zadań publicznych (art. 163 Konstytucji) i ustaw samorządowych (art. 6 i 7 u.s.g., art. 2 u.s.p., art. 2 ust. 2 u.s.w.), dysponowanie tymi samymi prawnymi środkami działania co administracja państwa. Z powyższego wynika jednoznacznie, że samorząd terytorialny został z mocy prawa wyposażony w szczególne atrybuty — atrybuty władzy publicznej ${ }^{8}$. Niezależnie od tego jednostki samorządu terytorialnego są wyposażone w osobowość prawną niezbędną do samodzielnego występowania w stosunkach cywilnoprawnych. Cywilistyczne rozumienie osobowości prawnej jednostek samorządu terytorialnego jest niewątpliwie uzasadnione przede wszystkim odrębnością majątkową jednostek samorządowych (mienie komunalne) i samodzielnością finansową (własny budżet i niezależna gospodarka finansowa) oraz potrzebą występowania w obrocie prawnym we własnym imieniu.

Natomiast odnośnie do kryterium osobowości prawnej stowarzyszeń jednostek samorządu terytorialnego (komunalnych) przyjmuje się, iż byt tych instytucji opiera się na prawie prywatnym. Pozostają bowiem w zarządzie prywatnoprawnym. $Z$ tego też względu nie należą do kategorii podmiotów administracji publicznej ${ }^{9}$. Tak np., w odróżnieniu od związków samorządowych, nie są powołane do wykonywania funkcji administracji publicznej, a zwłaszcza stanowienia aktów władczych ${ }^{10}$.

${ }^{6}$ W myśl art. 165 Konstytucji RP jednostki samorządu terytorialnego mają osobowość prawną; przysługują im prawo własności i inne prawa majątkowe, a samodzielność tych jednostek podlega ochronie sądowej.

7 Zob. T. Rabska, Pozycja samorzadu terytorialnego w Konstytucji, „Ruch Prawniczy, Ekonomiczny i Socjologiczny" 1995, z. 2, s. 43.

8 Ibidem, s. 45.

9 Por. H. Izdebski, M. Kulesza, Administracja publiczna. Zagadnienia ogólne, Warszawa 2004, s. 144.

10 Zob. Z. Leoński, Zarys prawa administracyjnego, Warszawa 2004, s. 194. 
Należałoby to jednakże uzupełnić, ponieważ różnica między stowarzyszeniami komunalnymi a jednostkami samorządu terytorialnego nie leży w przeciwstawności ich celów, lecz w odmienności sposobu ich realizacji. Zgodnie z art. 10 ust. 1 u.s.g. wykonywanie zadań publicznych może być realizowane w drodze współdziałania między jednostkami samorządu terytorialnego. Na podstawie powyższego przepisu jedną z form współpracy jednostek samorządu terytorialnego (obok związków komunalnych i porozumień międzygminnych) są stowarzyszenia jednostek samorządu terytorialnego. W związku z tym, że wspieranie i upowszechnianie idei samorządności (art. 7 ust. 1 pkt 17 u.s.g.) stanowi przykład zadania własnego gmin, należałoby uznać, że zadanie to gmina może realizować przez stowarzyszenie gmin (art. 84 ust. u.s.g.) lub samodzielnie ${ }^{11}$.

Pozostaje jednak zasadnicza kwestia o charakterze już dyskusyjnym, dotycząca ograniczonego zrzeszania się gmin tylko w celu wspierania idei samorządu terytorialnego oraz obrony wspólnych interesów (art. 84 ust. 1 u.s.g.). Tak ogólnie i szeroko zakreślone cele mają charakter uniwersalny ${ }^{12}$. Można się więc zastanawiać, jaki mają sens prawny i jakie pociągają za sobą skutki. Ze względu na swą ogólnikowość dopuszczają z jednej strony dużą swobodę samorządu w wyznaczaniu rozwoju gminy i bliższym decydowaniu o kierunkach zamierzeń i działań $^{13}$. Z kolei cel stowarzyszeń na poziomie powiatu i województwa nie został sprecyzowany. Wydaje się jednak, że nie można ograniczyć celu „wspierania idei samorządu terytorialnego oraz obrony wspólnych interesów" jedynie do stowarzyszeń gmin. W związku z tym, że zarówno powiaty (art. 75 ust. 1 u.s.p.), jak i województwa (art. 8 b ust. 1 u.s.w.) mogą tworzyć stowarzyszenia łącznie z gminami, konieczne jest przyjęcie takiego kierunku ich działalności, który byłby zgodny z wprowadzonymi wcześniej celami wynikającymi z ustawy o samorządzie gminnym. Będzie to miało decydujące znaczenie dla ich właściwego, merytorycznie uzasadnionego powiązania, a następnie bezkolizyjnej realizacji zamierzonych celów. Ważne jest również, aby wszystkie przepisy ustaw samorządowych dążyły do realizacji wspólnych zasad oraz do uwiarygodnienia podmiotowości stowarzyszeń (gmin, powiatów i województw) w prowadzeniu i realizowaniu idei samorządno-

11 K. Bandarzewski, [w:] Ustawa o samorzadzie gminnym. Komentarz, red. P. Chmielnicki, LexisNexis, 2013, s. 235.

$12 \mathrm{~W}$ aspekcie celów, jakie mają przyświecać gminom dla tworzenia stowarzyszeń na podstawie delegacji zawartej w art. 4 ust. 1 u.s.g., wypowiadał się m.in. sąd administracyjny, wskazując, że przepis ten formułuje cele stowarzyszeń w sposób ogólny. Zarówno wspieranie idei samorządu terytorialnego, jak i obrona wspólnych interesów zawierają w sobie „obszerną i bogatą treść” Wyrok NSA z dnia 17 października 2008 r., I OSK 483/08, LEX nr 523249.

13 Jak wyjaśniono w uzasadnieniu uchwały Sądu Najwyższego z dnia 30 kwietnia 1993 r. (sygn. III CZP 48/93, OSNC 1993/11/200), stowarzyszenia gmin mają służyć dwóm celom. Pierwszy z nich, którym jest wspieranie idei samorządu terytorialnego, może być uznany za wspólny dla wszystkich gmin. Ten cel może łączyć w zasadzie nieograniczoną liczbę gmin i skłaniać je do utworzenia jednego stowarzyszenia. 
ści lokalnej i regionalnej. Dobrze przygotowane przepisy zapewniłyby tak bardzo potrzebną w tej dziedzinie przejrzystość zasad postępowania.

Jakkolwiek drugi ze wskazanych celów stowarzyszeń gmin, jakim jest obrona wspólnych interesów, nie został uregulowany zbyt precyzyjnie, to jednak w odniesieniu do powyższego w literaturze wskazuje się, że „obrona wspólnych interesów przez stowarzyszenie gmin powinna obejmować uprawnienie (a nawet obowiązek) wypowiadania się stowarzyszenia w sprawach publicznych dotyczących obrony wspólnych interesów gmin" ${ }^{14}$. Przy czym działania podejmowane przez stowarzyszenia gmin polegające na obronie wspólnych interesów swoich członków mogą polegać m.in. na: możliwości wypowiadania się w przedmiocie projektowanych aktów normatywnych związanych z działalnością gmin, a także na prezentowaniu stanowisk w środkach masowego przekazu, jak również podejmowaniu działań informacyjnych czy konstruowaniu opinii w zakresie obrony interesów gmin ${ }^{15}$. Jednocześnie podmioty te mogą podejmować aktywne działania lobbingowe zmierzające do zmiany przepisów stanowiących podstawę prawną działań jednostek samorządu terytorialnego.

$\mathrm{Na}$ tym etapie stowarzyszenia gmin należałoby więc traktować jako gminne osoby prawne, realizujące cele samorządu terytorialnego ${ }^{16}$. Ta forma organizacyjno-prawna będzie na ogół uzupełnieniem działalności samorządu terytorialnego, formą rozwijającą się, ale bez szczególnych tendencji do wypierania czy zastępowania jednostek samorządu terytorialnego. Nieprzypadkowo więc szczególne zastosowanie ma charakter celów określonych w art. 84 u.s.g. Splatają się tu w wyraźny sposób interesy jednostek samorządu terytorialnego. Przepis ten stanowi istotny wyjątek od tworzenia stowarzyszeń przez osoby fizyczne, a to z tego względu, iż wskazane cele tworzenia stowarzyszeń gmin należy traktować jako wyczerpujące ${ }^{17}$. Trzeba jednocześnie zaznaczyć, iż do takich stowarzyszeń należy stosować „odpowiednio”, a więc z odpowiednimi modyfikacjami lub wcale, przepisy p.o.s. Wobec istniejącej wątpliwości, czy rzeczywiście wszystkie przepisy tej ustawy mogą być stosowane odpowiednio - wydaje się, że część przepisów powinna być stosowana wprost (tak np. nadzór nad stowarzyszeniami powinien być sprawowany wyłącznie na podstawie p.o.s.), natomiast część — wszędzie tam, gdzie występuje specyfika stowarzyszenia gmin — powinna być stosowana odpowiednio $^{18}$ (np. kryterium celów stowarzyszeń gmin).

14 P. Chmielnicki, P. Dobosz, [w:] Ustawa o samorzadzie..., s. 235.

15 K. Bandarzewski, [w:] Ustawa o samorzadzie..., s. 845.

16 Por. B. Dolnicki, Samorzad terytorialny, Warszawa 2012, s. 353.

17 Zob. A. Kidyba, Prawo handlowe, Warszawa 2006, s. 705.

18 Zob. ibidem. 


\section{STOWARZYSZENIA JEDNOSTEK SAMORZĄDU TERYTORIALNEGO A ORGANIZACJE POZARZĄDOWE}

We współczesnej doktrynie pojęcie stowarzyszenia jednostki samorządu terytorialnego utożsamiane jest niekiedy z pojęciem stowarzyszenia (jako organizacji pozarządowej) w rozumieniu art. 2 ust. 1 p.o.s. jako dobrowolnego, samorządnego, trwałego zrzeszenia o celach niezarobkowych ${ }^{19}$. Argumentacja takiego stanowiska nie jest w pełni przekonywająca: opiera się na przyjęciu, iż do stowarzyszeń tworzonych przez wskazane jednostki samorządowe stosuje się postanowienia prawa o stowarzyszeniach, a wobec stowarzyszeń tych jednostek prowadzących działalność pożytku publicznego - ustawę z dnia 24 kwietnia 2003 r. o działalności pożytku publicznego i o wolontariacie ${ }^{20}$.

Odmienność dwóch form organizacyjnych — stowarzyszenia jako organizacji pozarządowej i stowarzyszenia jednostki samorządu terytorialnego - nie podlega dyskusji. Jednakże wyłącznie ten fakt nie stoi jeszcze na przeszkodzie do zaliczenia obu rodzajów form organizacyjnych do wspólnego układu podmiotów prowadzących działalność społecznie użyteczną w sferze realizacji zadań określonych w u.d.p.p.w. (art. 3 ust. 3 pkt 2). Jakkolwiek stowarzyszenia jednostek samorządu terytorialnego służą w szczególny sposób realizacji zadań pożytku publicznego, to jednak nie może to oznaczać równorzędnego ich traktowania z organizacjami pozarządowymi.

W sensie prawnym nie wydaje się dostatecznie uzasadnione utożsamianie pojęcia stowarzyszenia jednostki samorządu terytorialnego z zakresem pojęcia organizacji pozarządowej. Może zachodzić obawa nieuchwycenia cech specyficznych dla tego typu podmiotów. Skrajną byłaby też tendencja przypisywania każdemu podmiotowi, który wykonuje działalność pożytku publicznego w sferze zadań publicznych określonych w u.d.p.p.w., statusu organizacji pozarządowej.

Tak np. kryterium samorządności ${ }^{21}$ na gruncie art. 2 ust 2 p.o.s. daje dużą dowolność celów ogólnospołecznych realizowanych przez stowarzyszenie. Natomiast odnośnie do kryterium celów stowarzyszeń gmin (art. 84 ust. 1 u.s.g.) przepis ten stanowi lex specialis, jeśli chodzi o możliwość udziału gminy w stowarzyszeniu, i ma prymat pierwszeństwa przed regulacją zawartą w ustawie Prawo o stowarzyszeniach.

19 Ustawa z dnia 7 kwietnia 1989 r. — Prawo o stowarzyszeniach, tekst jedn. Dz.U. 2015 poz. 1393.

20 Tekst jedn. 2016 poz. 239.

21 Jakkolwiek cecha samorządności odzwierciedla pewien zakres autonomii wewnętrznej stowarzyszenia, określoną sferę niepodlegającą ingerencji organów państwowych w trybie poleceń czy dyrektyw — zob. L. Wiśniewski, Model prawny stowarzyszeń, Warszawa 1974, s. 7 — to jednak wyszczególnienie tej cechy przez ustawodawcę przydaje stowarzyszeniu status samodzielnej i niezależnej organizacji w określaniu swoich celów, programów działania czy struktur organizacyjnych. 
Z tych względów wydaje się celowe, aby przy ustalaniu charakteru prawnego stowarzyszeń komunalnych wziąć pod uwagę następujące kwestie:

1. W trybie art. 3 ust. 2 u.d.p.p.w. organizacjami pozarządowymi są osoby prawne lub jednostki organizacyjne nieposiadające osobowości prawnej (którym odrębna ustawa przyznaje zdolność prawną) niebędące jednostkami sektora finansów publicznych (w rozumieniu ustawy o finansach publicznych) i niedziałające w celu osiągnięcia zysku, czyli m.in. fundacje i stowarzyszenia. Oparcie prawnej definicji organizacji pozarządowych na koncepcji odrębności tych podmiotów od jednostek sektora finansów publicznych ma znaczenie przede wszystkim z punktu widzenia braku powiązań organizacyjnych i finansowych wyróżnionych organizacji z jednostkami tego sektora. Za organizacje pozarządowe można uważać te podmioty, które nie wchodzą w zakres pojęciowy podmiotów państwowych, w tym rządowych, i podmiotów samorządowych. Ponadto, odnosząc się do zagadnienia możliwości dotowania zadań zlecanych przez jednostki samorządu terytorialnego organizacjom pozarządowym (art. 127 ust. 1 pkt 1 lit. e, art. 151 ust. 1 i art. 221 u.f.p.), można powiedzieć, że są to „podmioty stojące na zewnątrz samorządu terytorialnego, to znaczy nie powiązane z samorządem organizacyjnie ani kapitałowo"22.

Należy jeszcze zwrócić uwagę, że zakres podmiotowy sektora finansów w świetle art. 9 pkt 14 ustawy z dnia 27 sierpnia 2009 r. o finansach publicznych $^{23}$ jest rozległy i zróżnicowany ${ }^{24}$. Szczególnie sporne w literaturze jest zagadnienie statusu samorządowych osób prawnych. Trudności teoretyczne w tym zakresie pogłębia stan ustawodawstwa. Trudno bowiem pojęcie samorządowych osób prawnych konstruować wyłącznie na podstawie kryterium normatywnego (ustawa o samorządzie powiatowym ${ }^{25}$ i o samorządzie województwa ${ }^{26}$ ) czy na

22 Zob. K. Sawicka, Dotacje z budżetu gminy jako szczególna forma wydatków publicznych, [w:] Ksiega Jubileuszowa Profesora Marka Mazurkiewicza: studia z dziedziny prawa finansowego, prawa konstytucyjnego i ochrony środowiska, red. R. Mastalski, Wrocław 2001, s. 18.

23 Dz.U. 2013 poz. 885 z późn. zm.

24 Sektor ten tworzą m.in.: organy władzy publicznej, w tym organy administracji rządowej, organy kontroli państwowej i ochrony prawa oraz sądy i trybunały; jednostki samorządu terytorialnego oraz ich związki; związki metropolitalne; jednostki budżetowe; samorządowe zakłady budżetowe; agencje wykonawcze; instytucje gospodarki budżetowej; państwowe fundusze celowe; Zakład Ubezpieczeń Społecznych i zarządzane przez niego fundusze oraz Kasa Rolniczego Ubezpieczenia Społecznego i fundusze zarządzane przez Prezesa Kasy Rolniczego Ubezpieczenia Społecznego; Narodowy Fundusz Zdrowia; samodzielne publiczne zakłady opieki zdrowotnej; uczelnie publiczne; Polska Akademia Nauk i tworzone przez nią jednostki organizacyjne; państwowe i samorządowe instytucje kultury; inne państwowe lub samorządowe osoby prawne utworzone na podstawie odrębnych ustaw w celu wykonywania zadań publicznych, z wyłączeniem przedsiębiorstw, instytutów badawczych, banków i spółek prawa handlowego.

25 Art. 46: „Powiatowymi osobami prawnymi, poza powiatem, są samorządowe jednostki organizacyjne, którym ustawy przyznają wprost taki status, oraz te osoby prawne, które mogą być tworzone na podstawie odrębnych ustaw wyłącznie przez powiat".

26 Art. 47: „Wojewódzkimi osobami prawnymi, poza województwem, są samorządowe jednostki organizacyjne, którym ustawy przyznają wprost taki status, oraz te osoby prawne, które mogą być tworzone na podstawie odrębnych ustaw wyłącznie przez województwo". 
podstawie kryterium podmiotu tworzącego osobę prawną (ustawa o gospodarce nieruchomościami ${ }^{27}$ ). Wskazane regulacje prawne nie tylko nie wyjaśniają istoty samorządowych osób prawnych, lecz także dają możliwość bardzo różnej interpretacji, ponieważ zupełnie inne znaczenie ma i inne pociąga za sobą skutki sposób definiowania powiatowej oraz wojewódzkiej osoby prawnej przez odniesienie wyłącznej kompetencji jednostki samorządu terytorialnego do tworzenia danego podmiotu (art. 46 ust. 2 u.s.p. i art. 47 ust. 2 u.s.w.), a inne - definiowanie samorządowych osób prawnych oparte na kryterium organu tworzącego osobę prawną (art. 4 pkt 9a u.g.n. $)^{28}$. Należy również wziąć pod uwagę, że jakkolwiek ustawa o samorządzie gminnym nie definiuje pojęcia gminnej osoby prawnej, to jednak stanowi, że może ona prowadzić działalność gospodarczą wykraczającą poza zadania użyteczności publicznej wyłącznie w przypadkach określonych w odrębnej ustawie (art. 9 ust. 2 u.s.g.) ${ }^{29}$. Charakterystyczny jest zwłaszcza fakt, że kategoria gminnych osób prawnych może obejmować podmioty zróżnicowane pod względem charakteru prawnego. Wynika to z treści art. 43 u.s.g., zgodnie z którym mieniem komunalnym (gminnym) są własność oraz inne prawa majątkowe należące do poszczególnych gmin i ich związków, a także mienie innych gminnych osób prawnych, w tym przedsiębiorstw. Powyższe rozwiązanie nie ogranicza kategorii gminnych osób prawnych wyłącznie do gmin i związków międzygminnych, akcentuje tym samym możliwość istnienia poza wskazanymi podmiotami również innych samorządowych osób prawnych. Co więcej, gminne osoby prawne, jak sama nazwa wskazuje, muszą posiadać przyznaną w sposób wyraźny przez przepisy prawa osobowość prawną. Będą to np. stowarzyszenia gmin ${ }^{30}$, które podlegają obowiązkowi rejestracji w Krajowym Rejestrze Sądowym. Z chwilą wpisania do rejestru stowarzyszenie gmin uzyskuje osobowość prawną.

Nasuwa się jeszcze pytanie, czy samorządowymi osobami prawnymi są stowarzyszenia powiatów i województw. Na to pytanie trudno znaleźć jednoznaczną odpowiedź, albowiem sam termin „samorządowe osoby prawne”, jakkolwiek używany w ustawie o samorządzie powiatowym i ustawie o samorządzie województwa, nie ma definicji, która zyskałaby powszechną akceptację. W definicjach zawartych w art. 46 ust. 2 u.s.p. i art. 47 ust. 2 u.s.w. wskazano, iż powiatową (wojewódzką) osobą prawną, poza powiatem (województwem), są samorządowe jednostki organizacyjne, którym ustawy przyznają wprost taki status, oraz te oso-

27 Ustawa z dnia 21 sierpnia 1997 r. o gospodarce nieruchomościami (tekst jedn. Dz.U. 2016 poz. 2147 z późn. zm.).

28 Zgodnie z art. 4 pkt 9a ustawy „ilekroć w ustawie jest mowa o samorządowej osobie prawnej — należy przez to rozumieć osoby prawne powoływane lub tworzone przez organy jednostek samorządu terytorialnego".

29 Art. 9: „Gmina oraz inna gminna osoba prawna może prowadzić działalność gospodarczą wykraczającą poza zadania o charakterze użyteczności publicznej wyłącznie w przypadkach określonych w odrębnej ustawie".

30 Zob. B. Dolnicki, op. cit., s. 353. 
by prawne, które mogą być tworzone na podstawie odrębnych ustaw wyłącznie przez powiat (województwo) ${ }^{31}$. Wyklucza to możliwość zakwalifikowania jako samorządowych osób prawnych stowarzyszeń powiatów (województw), gdyż są one utworzone przez powiaty (województwa), a nie powiat (województwo), jak stanowią wyróżnione przepisy. Spieranie się co do tego jest daremne. W każdym razie pewne jest, że w rozumieniu art. 4 pkt 9a u.g.n. samorządowymi osobami prawnymi są podmioty powołane lub tworzone przez organy jednostek samorządu terytorialnego, tzn. utworzone przez radę (sejmik) wójta (burmistrza, prezydenta lub zarząd jednostki samorządu terytorialnego). Przemawia to nie przeciwko, lecz wręcz za koniecznością rozszerzenia zakresu pojęciowego samorządowych osób prawnych również do stowarzyszeń jednostek samorządu terytorialnego.

Nie można wszak zaprzeczyć, że w obowiązującym ustawodawstwie istnieje zróżnicowanie zakresu pojęć: samorządowych osób prawnych i stowarzyszeń jednostek samorządu terytorialnego, albowiem jeżeli sięgniemy do art. 1 ust. 2 ustawy z dnia 7 października 1992 r. o regionalnych izbach obrachunkowych ${ }^{32}$, zauważymy, że w przepisie tym obok stowarzyszeń gmin, stowarzyszeń powiatów oraz stowarzyszeń gmin i powiatów wymieniono samorządowe jednostki organizacyjne, w tym samorządowe osoby prawne, z czego wynika, że wskazany przepis nie zalicza ich do samorządowych osób prawnych. Do odmiennego wniosku prowadzi natomiast analiza art. 2 ust. 2 ustawy z dnia 23 grudnia 1994 r. o Najwyższej Izbie Kontroli (tekst jedn. Dz.U. 2017 poz. 524.). W świetle wyróżnionego przepisu Najwyższa Izba Kontroli może kontrolować działalność organów samorządu terytorialnego, samorządowych osób prawnych i innych samorządowych jednostek organizacyjnych. Nie do pomyślenia jest wszak uznanie, iż wszelkiego rodzaju związki, stowarzyszenia i tym podobne zrzeszenia jednostek samorządu terytorialnego są wyłączone spod kontrolnych kompetencji NIK ${ }^{33}$.

2. Na zróżnicowaną pozycję prawną stowarzyszeń jednostek samorządu terytorialnego wobec stowarzyszeń powszechnych jako organizacji pozarządowych wpływają jeszcze inne czynniki. Chodzi bowiem przede wszystkim o to, iż stowarzyszenia jednostek samorządu terytorialnego muszą posiadać osobowość prawną. Tworzenie tzw. stowarzyszeń komunalnych „zwykłych” jest niedopuszczalne bez względu na to, jakim celom miałyby służyć. Kolejnym argumentem przemawiającym za odrębnością stowarzyszeń jednostek samorządu terytorialnego od stowarzyszeń osób fizycznych są uregulowania przyjęte w art. 220 ust. 1 ustawy o finansach

31 W literaturze wskazuje się na dwie możliwości kreowania tzw. samorządowych osób prawnych. Pierwsza polega na ich utworzeniu w drodze ustawy, która nadaje im wskazany status prawny. Druga wskazuje na dopuszczalność ich utworzenia wyłącznie przez powiaty i województwa na podstawie szczególnych przepisów (np. stowarzyszenia powiatów, województw). Por. Z problemów administracji. Administracja publiczna, red. T. Maciejewski, J. Gierszewski, Chojnice 2010, s. 144.

32 Tekst jedn. Dz.U. 2012 poz. 1113 z późn. zm.

33 Por. A. Szewc, O pojęciu ,jednostka organizacyjna” w polskim prawie samorzadu terytorialnego, „Ruch Prawniczy, Ekonomiczny i Socjologiczny” 2005, z. 3, s. 110. 
publicznych ${ }^{34} . \mathrm{Z}$ przepisu art. 220 ust. 1 ustawy o finansach publicznych wyni$\mathrm{ka}$, że z budżetu jednostki samorządu terytorialnego może być udzielona innym jednostkom samorządu terytorialnego pomoc finansowa w formie dotacji celowej lub pomoc rzeczowa. Jednocześnie przepisy samorządowych ustaw ustrojowych enumeratywnie wymieniają podmioty uprawnione do otrzymania pomocy. I tak w trybie art. 10 ust. 2 u.s.g. oraz art. 7a u.s.p..$^{35}$ gminy, związki międzygminne oraz stowarzyszenia jednostek samorządu terytorialnego, powiaty, związki lub stowarzyszenia powiatów mogą sobie wzajemnie lub innym jednostkom samorządu terytorialnego udzielać pomocy, w tym finansowej. Natomiast przepis art. $8 \mathrm{a}$ u.s.w. ${ }^{36}$ stanowi, iż województwa samorządowe mogą sobie wzajemnie bądź innym jednostkom samorządu terytorialnego udzielać pomocy, w tym finansowej. Tak więc w świetle wyróżnionych przepisów nie może być udzielona pomoc rzeczowa dla podmiotu niezaliczanego do sektora finansów publicznych i niedziałającego w celu osiągnięcia zysku, co przemawia za koniecznością wyodrębnienia stowarzyszeń jednostek samorządu terytorialnego z organizacji pozarządowych.

W tym kontekście duże znaczenie ma również kwestia nabycia członkostwa zwykłego w stowarzyszeniach jednostek samorządu terytorialnego. Zarówno nabycie, jak i utrata członkostwa w tych stowarzyszeniach następuje na mocy uchwały Zarządu podejmowanej na skutek woli jednostki samorządu terytorialnego wyrażonej w formie uchwały rady gminy (art. 18 ust. 2 pkt 12 u.s.g.), rady powiatu (art. 12 pkt 8 lit. fu.s.p.) lub sejmiku województwa (art. 18 pkt 18 u.s.w.). Wypada też zaznaczyć, że uchwały organów stanowiących jednostek samorządu terytorialnego zarówno $\mathrm{w}$ przedmiocie utworzenia, jak i przystąpienia do istniejącego stowarzyszenia komunalnego podlegają nadzorowi wojewody w trybie ustaw samorządowych (art. 85 u.s.g. w zw. z art. 18 ust. 2 pkt 12, art. 76 u.s.p. w zw. $\mathrm{z}$ art. 12 pkt 8 lit. f, art. 78 u.s.w. w zw. z art. 18 pkt 18). $\mathrm{Z}$ tego względu trudno istotę tych instytucji prawnych wydzielić z całokształtu relacji między nimi a jednostkami samorządu terytorialnego. Przesądza to o zadaniach stowarzyszeń oraz ich charakterze prawnym.

$\mathrm{Z}$ drugiej strony jednak nie można negować faktu, że przepisy prawne określające strukturę organizacyjną stowarzyszeń komunalnych są zawarte w prawie o stowarzyszeniach. Zgodnie z art. 84 ust. 2-3 u.s.g. organizację, zadania i tryb pracy stowarzyszenia utworzonego przez gminy określa jego statut. Stosownie do treści art. 10 ust. 1 p.o.s. powinien on regulować w szczególności: nazwę stowarzyszenia, odróżniającą je od innych stowarzyszeń, organizacji i instytucji; teren działania i siedzibę stowarzyszenia; cele i sposoby ich realizacji; sposób naby-

34 Ustawa z dnia 27 sierpnia 2009 r. o finansach publicznych (tekst jedn. Dz.U. 2013. poz. 885 z późn. zm.).

35 Ustawa z dnia 5 czerwca 1998 r. o samorządzie powiatowym (tekst jedn. Dz.U. 2016 poz. 814).

36 Ustawa z dnia 5 czerwca 1998 r. o samorządzie województwa (tekst jedn. Dz.U. 2013 poz. 596 z późn. zm.). 
wania i utraty członkostwa; przyczyny utraty członkostwa; prawa i obowiązki członków; władze stowarzyszenia, tryb dokonywania ich wyboru, uzupełniania składu oraz ich kompetencje; możliwość otrzymywania przez członków zarządu wynagrodzenia za czynności wykonywane w związku z pełnioną funkcją; sposób reprezentowania stowarzyszenia, w szczególności sposób zaciągania zobowiązań majątkowych, a także warunki ważności uchwał władz stowarzyszenia; sposób uzyskiwania środków finansowych oraz ustanawiania składek członkowskich; zasady dokonywania zmian statutu oraz sposób rozwiązania stowarzyszenia. Statut może przewidywać tworzenie terenowych jednostek organizacyjnych stowarzyszenia (art. 10a p.o.s.). Ze względów teoretycznych, opierając się nadto na obowiązującym ustawodawstwie, należy przyjąć, iż w wypadku stowarzyszeń komunalnych będzie to dotyczyć przede wszystkim tych jednostek organizacyjnych, które mogą uzyskać osobowość prawną.

Dla dokonania ustaleń teoretycznych należałoby również podnieść kwestię członkostwa w stowarzyszeniach komunalnych. Wątpliwości wywołała zwłaszcza kwestia uczestnictwa jednostek samorządu terytorialnego w stowarzyszeniach osób fizycznych w charakterze członków wspierających. W tym zakresie w orzecznictwie sądowym i doktrynie występowały dość daleko idące rozbieżności. Tak np. WSA w wyroku z dnia 5 czerwca 2008 r. (sygn. akt II SA/Rz 266/08) wykluczył możliwość przystąpienia gminy jako członka wspierającego do stowarzyszenia działającego na podstawie p.o.s. i niemającego charakteru stowarzyszenia jednostek samorządu terytorialnego ${ }^{37}$. Odmienne stanowisko prezentowano w doktrynie, zwracając uwagę, iż jednostki samorządu terytorialnego mogą przystępować do stowarzyszeń osób fizycznych w charakterze członków wspierających, czy też do związków stowarzyszeń ${ }^{38}$.

W aktualnym stanie prawnym nie ma przepisu, który zakazywałby jednostkom samorządu terytorialnego, jako osobom prawnym, przystępowania do już istniejących stowarzyszeń w charakterze członka wspierającego. Taką możliwość daje art. 10 ust. 3 p.o.s., zgodnie $\mathrm{z}$ którym osoba prawna może być tylko wspierającym członkiem stowarzyszenia ${ }^{39}$. Kwestią sporną pozostaje jednak definicja członka

37 Wyrok WSA w Rzeszowie z dnia 5 czerwca 2008 r. (sygn. akt II SA/Rz 266/08), LEX nr 511465. Kwestia interpretacji art. 84 ust. 1 była też przedmiotem innych rozważań w orzecznictwie - m.in. wyrok WSA we Wrocławiu z dnia 3 marca 2004 r., II SA/Wr 2638/03, niepubl.; wyroki WSA w Rzeszowie - z dnia 25 stycznia 2006 r., II SA/Rz 524/05; z dnia 27 listopada 2007 r., II SA/ Rz 536/07, niepubl., gdzie sądy zaaprobowały pogląd, iż możliwość zrzeszania się gmin ograniczona jest $\mathrm{z}$ woli ustawodawcy tylko do zrzeszania się z innymi jednostkami samorządu terytorialnego, http://orzeczenia.nsa.gov.pl/doc/8FC63E08EF.

38 Zob. w tej kwestii: P. Suski, Stowarzyszenia i fundacje, Warszawa 2008, s. 224; K. Bandarzewski, [w:] Ustawa o samorządzie gminnym. Komentarz, Warszawa 2004, s. 500; Z. Godecki, Stowarzyszenia gmin, ST 1993, nr 1-2, s. 77 n.; Ustawa o samorzadzie gminnym. Komentarz, red. R. Hauser, Z. Niewiadomski, Warszawa 2011, s. 693.

39 Pogląd ten potwierdza wyrok WSA w Poznaniu z dnia 15 lipca 2016 r. (sygn. akt II SA/ Po 317/16). 
wspierającego, albowiem żaden przepis nie wyjaśnia, jaka jest różnica między członkiem zwykłym (rzeczywistym) a członkiem wspierającym. Jakkolwiek sama nazwa „członkowie wspierający” mogłaby sugerować specjalne wspieranie stowarzyszenia, polegające także na wspieraniu materialnym, dodatkowo ponad to, co czynią członkowie zwykli ${ }^{40}$, to jednak może też wynikać np. z prawa ich udziału z głosem doradczym w pracach stowarzyszenia czy regularnego otrzymywania informacji o jego działalności. Tak więc postanowienia statutu decydują o uzyskaniu statusu członka zwykłego lub członka wspierającego oraz o ich prawach i obowiązkach. Wynika to z założenia, iż statut od chwili zarejestrowania powinien być traktowany jako norma prawna z jednej strony realizująca art. 38 k.c., z drugiej zaś będąca zbiorem przepisów regulujących stosunki wewnętrzne stowarzyszenia ${ }^{41}$.

Istotne i charakterystyczne dla stowarzyszeń komunalnych jest uzupełnienie, iż założycielami i członkami zwykłymi (rzeczywistymi) mogą być gminy, powiaty i samorządowe województwa. Natomiast członkiem wspierającym takich stowarzyszeń może być polska i zagraniczna osoba prawna lub fizyczna, która zadeklaruje udział w realizacji ich celów. Jednocześnie należy zaznaczyć, iż w odróżnieniu od stowarzyszeń powszechnych (jako organizacji pozarządowych) członkami władz stowarzyszeń mogą być tylko członkowie organów jednostek samorządu terytorialnego, ich zastępcy, a także członkowie rad (sejmików). Wyboru członka rzeczywistego dokonuje Zarząd Stowarzyszenia w drodze uchwały na podstawie uchwały organu stanowiącego jednostki samorządu terytorialnego. Znajduje to wyraz $\mathrm{w}$ uregulowaniach zawartych $\mathrm{w}$ art. 18 ust. 2 pkt 12 u.s.g., art. 12 pkt 8 lit. f u.s.p., art. 18 pkt 18 u.s.w. oraz art. 16 ust. 1 p.o.s., zgodnie z którym ,sąd rejestrowy wydaje postanowienie o wpisie stowarzyszenia do Krajowego Rejestru Sądowego po stwierdzeniu, że jego statut jest zgodny z przepisami prawa i założyciele spełniają wymagania określone ustawą". W tym miejscu należy stwierdzić, że chodzi tu nie tylko o zgodność z przepisami samego prawa o stowarzyszeniach, lecz także z przepisami innych ustaw (w tym - samorządowych).

Z problematyką stowarzyszeń jednostek samorządu terytorialnego łączy się nadto wiele problemów dodatkowych, uzupełniających, jak np. zagadnienie przeznaczenia majątku tych instytucji po ich likwidacji ${ }^{42}$. Ponieważ nie podlegało dotąd dyskusji, że stowarzyszenie jednostek samorządu terytorialnego jest konstrukcją

40 A. Kidyba, op. cit., s. 706.

41 J. Blicharz, Pozycja prawna stowarzyszeń. Studium prawnoadministracyjne, Wrocław 1990, s. 36.

42 Zgodnie $\mathrm{z}$ art. 33 ust. 1 ust. 2 p.o.s. majątek stowarzyszenia powstaje ze składek członkowskich, darowizn, spadków, zapisów, dochodów z własnej działalności, dochodów z majątku stowarzyszenia oraz z ofiarności publicznej. Poza tym stowarzyszenie, z zachowaniem obowiązujących przepisów, może przyjmować darowizny, spadki i zapisy oraz korzystać z ofiarności publicznej. Z kolei w trybie art. 38 p.o.s. majątek zlikwidowanego stowarzyszenia przeznacza się na cel określony w statucie lub w uchwale walnego zebrania członków (zebrania delegatów) o likwidacji stowarzyszenia. W razie braku postanowienia statutu lub uchwały w tej sprawie sąd orzeka o przeznaczeniu majątku na określony cel społeczny. 
prawną, służącą przede wszystkim wspólnej reprezentacji interesów tych jednostek samorządowych oraz że na realizację tego celu wydziela ono odpowiedni majątek (w wyniku podjętej uchwały organów tych jednostek jako członków-założycieli i członków rzeczywistych), należałoby konsekwentnie wyciągnąć dalszy wniosek, że po likwidacji stowarzyszenia majątek ten przechodzi na własność poszczególnych członków, po zaspokojeniu wszelkich zobowiązań i roszczeń wierzycieli.

Jednakże tutaj odczuwa się jeszcze pewne niedociągnięcia zarówno w przepisach prawnych, praktyce, jak i ustaleniach teoretycznych. Dotyczy to zwłaszcza zapisu art. 38 p.o.s., w świetle którego w razie braku postanowienia statutu lub uchwały w tej sprawie sąd orzeka o przeznaczeniu majątku na określony cel społeczny. Trzeba też zaznaczyć, że pojęcie „celu społecznego” daje możliwość bardzo różnej interpretacji, albowiem jak pisze M. Wyrzykowski: „[...] jego treść jest ciągle zmieniającą się kompozycją i balansem różnorodnych wartości określonego

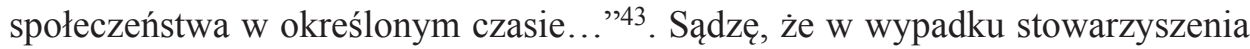
jednostek samorządu terytorialnego uzasadnione będzie dążenie do utrzymania dość wąskiego pojęcia celu społecznego, jako tego, dla którego realizacji założono stowarzyszenie ${ }^{44}$. Takie rozwiązanie jest celowe ze względu na wskazane cele tej instytucji prawnej, określone w u.s.g. jako wyczerpujące.

Biorąc to wszystko pod uwagę, należy przyjąć, że mimo stałej dyskusyjności charakteru prawnego stowarzyszeń jednostek samorządu terytorialnego, bezsporny jest fakt, iż stanowią one tę formę organizacyjno-prawną, która jest na ogół uzupełnieniem działalności samorządu terytorialnego. Służą one bowiem w szczególny sposób wspieraniu jego idei na tak ważnym jego odcinku, jakim jest wykonywanie zadań publicznych. Równocześnie sam termin „stowarzyszenia jednostek samorządu terytorialnego" ma określoną treść prawną i nie można go — bez bliższego zbadania treści — traktować jako równoznacznego z organizacją pozarządową.

\section{THE ISSUE OF LEGAL CHARACTER OF ASSOCIATIONS OF SELF-GOVERNMENT UNITS}

\section{Summary}

Although the legal character of associations of self-government units is disputable, it is beyond any doubt that they represent the organisational and legal form which usually complements the activity of self-government. They serve in particular way to support the idea of self-government within the area of performing of public tasks.

43 M. Wyrzykowski, Pojęcie interesu społecznego w prawie administracyjnym, Warszawa 1986, s. 209.

44 Interpretując cytowany przepis pozytywnie, przez „cele” należy rozumieć te cele, dla których realizacji założono stowarzyszenie, por. W. Czapiński, Prawo o stowarzyszeniach z komentarzami, Warszawa 1935, s. 53-54. Także w tej sprawie: J. Blicharz, Komentarze do ustaw: o zmianie imion i nazwisk, prawo o stowarzyszeniach, Wrocław 1997, s. 96. 